\title{
Front Matter: Volume 9934
}

, "Front Matter: Volume 9934," Proc. SPIE 9934, Terahertz Emitters, Receivers, and Applications VII, 993401 (1 December 2016); doi: 10.1117/12.2258527

SPIE Event: SPIE Nanoscience + Engineering, 2016, San Diego, California, United SPIE. States 


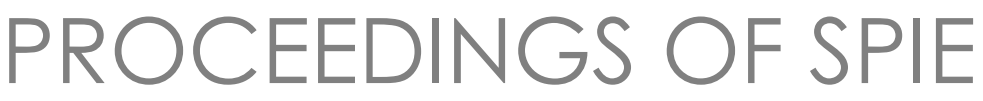

\title{
Terahertz Emitters, Receivers, and Applications VII
}

\author{
Manijeh Razeghi \\ Alexei N. Baranov \\ John M. Zavada \\ Dimitris Pavlidis \\ Editors
}

28-31 August 2016

San Diego, California, United States

Sponsored and Published by

SPIE

Volume 9934 
The papers in this volume were part of the technical conference cited on the cover and title page. Papers were selected and subject to review by the editors and conference program committee. Some conference presentations may not be available for publication. Additional papers and presentation recordings may be available online in the SPIE Digital Library at SPIEDigitallibrary.org.

The papers reflect the work and thoughts of the authors and are published herein as submitted. The publisher is not responsible for the validity of the information or for any outcomes resulting from reliance thereon.

Please use the following format to cite material from these proceedings:

Author(s), "Title of Paper," in Terahertz Emitters, Receivers, and Applications VII, edited by Manijeh Razeghi, Alexei N. Baranov, John M. Zavada, Dimitris Pavlidis, Proceedings of SPIE Vol. 9934 (SPIE, Bellingham, WA, 2016) Six-digit Article CID Number.

ISSN: 0277-786X

ISSN: 1996-786X (electronic)

ISBN: 9781510602595

ISBN: 9781510602601 (electronic)

Published by

SPIE

P.O. Box 10, Bellingham, Washington 98227-0010 USA

Telephone +1 3606763290 (Pacific Time) · Fax +1 3606471445

SPIE.org

Copyright @ 2016, Society of Photo-Optical Instrumentation Engineers.

Copying of material in this book for internal or personal use, or for the internal or personal use of specific clients, beyond the fair use provisions granted by the U.S. Copyright Law is authorized by SPIE subject to payment of copying fees. The Transactional Reporting Service base fee for this volume is $\$ 18.00$ per article (or portion thereof), which should be paid directly to the Copyright Clearance Center (CCC), 222 Rosewood Drive, Danvers, MA 01923. Payment may also be made electronically through CCC Online at copyright.com. Other copying for republication, resale, advertising or promotion, or any form of systematic or multiple reproduction of any material in this book is prohibited except with permission in writing from the publisher. The CCC fee code is 0277-786X/16/\$18.00.

Printed in the United States of America.

Publication of record for individual papers is online in the SPIE Digital Library.

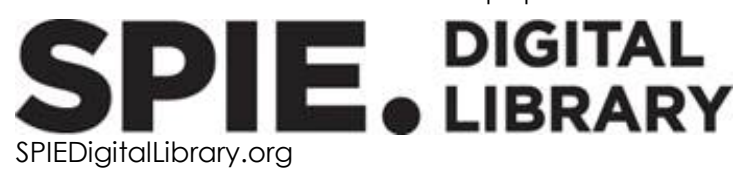

Paper Numbering: Proceedings of SPIE follow an e-First publication model. A unique citation identifier (CID) number is assigned to each article at the time of publication. Utilization of CIDs allows articles to be fully citable as soon as they are published online, and connects the same identifier to all online and print versions of the publication. SPIE uses a six-digit CID article numbering system structured as follows:

- The first four digits correspond to the SPIE volume number.

- The last two digits indicate publication order within the volume using a Base 36 numbering system employing both numerals and letters. These two-number sets start with $00,01,02,03,04,05$, $06,07,08,09,0 A, 0 B \ldots$.. OZ, followed by 10-1Z, 20-2Z, etc. The CID Number appears on each page of the manuscript. 


\title{
Contents
}

\author{
$\checkmark$ Authors \\ vii Conference Committee
}

\section{SESSION 1 THZ EMITTERS}

993405 Physical mechanisms of surface terahertz emission from semiconductors (Invited Paper) [9934-4]

993406 RT-CW: widely tunable semiconductor THz QCL sources (Keynote Paper) [9934-5]

\section{SESSION 2 FUNDAMENTALS OF THZ TECHNOLOGY I}

993407 Tunable and reconfigurable $\mathrm{THz}$ devices for advanced imaging and adaptive wireless communication (Invited Paper) [9934-6]

993409 Influence of disordered cover on cascade mechanism of medium response spectrum broadening at THz-TDS of substance [9934-8]

\section{SESSION $3 \quad$ THZ SPECTROSCOPY}

9934 OC New developments in THz quartz enhanced photoacoustic spectroscopy (Invited Paper) [9934-11]

9934 OE Multifrequency high precise subTHz-THz-IR spectroscopy for exhaled breath research (Invited Paper) [9934-13]

9934 OF Microwave-to-terahertz dielectric resonators for liquid sensing in microfluidic systems (Invited Paper) [9934-14]

\section{SESSION 4 THZ DETECTION AND APPLICATIONS}

9934 OG Novel ultrasensitive plasmonic detector of terahertz pulses enhanced by femtosecond optical pulses (Invited Paper) [9934-15]

$9934 \mathrm{OH} \quad$ Perspectives of DIG FinfETs for efficient terahertz detection applications [9934-16]

9934 Ol Plasmonic response of partially gated field effect transistors [9934-17] 
9934 ON Terahertz conductivity of ultra high electron concentration 2DEGs in NTO/STO heterostructures [9934-21]

\section{SESSION 6 THZ BIOSENSING}

9934 OP Application of terahertz spectroscopy for characterization of biologically active organic molecules in natural environment [9934-24]

9934 OS Terahertz devices, spectroscopy, and signal processing for biosensing (Invited Paper) [9934-27] 
Proc. of SPIE Vol. $9934993401-6$

Downloaded From: https://www.spiedigitallibrary.org/conference-proceedings-of-spie on 25 Apr 2023 Terms of Use: https://www.spiedigitallibrary.org/terms-of-use 


\section{Conference Committee}

Symposium Chairs

Harry A. Atwater, California Institute of Technology (United States)

Nikolay I. Zheludev, Optoelectronics Research Centre

(United Kingdom) and Nanyang Technological University

(Singapore)

Symposium Co-chairs

David L. Andrews, University of East Anglia (United Kingdom)

James G. Grote, Air Force Research Laboratory (United States)

\section{Conference Chairs}

Manijeh Razeghi, Northwestern University (United States)

Alexei N. Baranov, Université Montpellier 2 (France)

John M. Zavada, Polytechnic Institute of New York University

(United States)

Dimitris Pavlidis, National Science Foundation (United States)

\section{Conference Program Committee}

Maria Amanti, Université Paris 7-Denis Diderot (France)

Richard D. Averitt, University of California, San Diego (United States)

Stefano Barbieri, Université Paris 7-Denis Diderot (France)

Heribert Eisele, University of Leeds (United Kingdom)

Robert J. Grasso, EOIR Technologies (United States)

Sven Höfling, University of St. Andrews (United Kingdom)

Hiroshi Ito, Kitasato University (Japan)

Wojciech Knap, Université Montpellier 2 (France)

James Lloyd-Hughes, The University of Warwick (United Kingdom)

Stephen A. Lynch, Cardiff University (United Kingdom)

Juliette Mangeney, Ecole Normale Supérieure (France)

Oleg Mitrofanov, University College London (United Kingdom)

Gaël Mouret, Université du Littoral Côte d'Opale (France)

Naoki Oda, NEC Corporation (Japan)

Mauro F. Pereira, Sheffield Hallam University (United Kingdom)

Edik U. Rafailov, Aston University (United Kingdom)

Pascale Roy, Synchrotron SOLEIL (France)

Carlo Sirtori, Université Paris 7-Denis Diderot (France)

Zachary D. Taylor, University of California, Los Angeles (United States)

Roland Teissier, Université Montpellier 2 (France) 
Mark D. Thomson, Johann Wolfgang Goethe-Universität Frankfurt am Main (Germany)

Gintaras Valušis, Center for Physical Sciences and Technology

(Lithuania)

Miriam S. Vitiello, Consiglio Nazionale delle Ricerche (Italy)

Benjamin S. Williams, University of California, Los Angeles

(United States)

\section{Session Chairs}

1 THz Emitters

John M. Zavada, Polytechnic Institute of New York University

(United States)

Michael S. Shur, Rensselaer Polytechnic Institute (United States)

2 Fundamentals of THz Technology I

Edik U. Rafailov, Aston University (United Kingdom)

Vincenzo Spagnolo, Politecnico di Bari (Italy)

$3 \mathrm{THz}$ Spectroscopy

Mauro Fernandes Pereira, Sheffield Hallam University

(United Kingdom)

Vyacheslav A. Trofimov, M.V. Lomonosov Moscow State University

(Russian Federation)

$4 \mathrm{THz}$ Detection and Applications

Nguyen Q. Vinh, Virginia Polytechnic Institute and State University (United States)

Seongsin Margaret Kim, The University of Alabama (United States)

5 Fundamentals of THz Technology II

Norbert Klein, Imperial College London (United Kingdom)

Vladimir L. Vaks, Institute for Physics of Microstructures

(Russian Federation)

6 THz Biosensing

Manijeh Razeghi, Northwestern University (United States)

Alexei N. Baranov, Université Montpellier 2 (France) 